\title{
Song of the Barium Swallow
}

Siberian barrens fill

with mines and dams,

minds trained by one purpose,

the gut.

Mud nests hang in sluiceways,

from crossarms of power poles,

from armpits of miners and linemen.

There's a pile of porcelain line insulators

smashed at the foot of a pole.

A silver-throated

string of chromosomes

dives from her perch

with unlikely liquidity,

eyes filled

a thousand ways

chirrups barcode

to $\mathrm{x}$-rays. 